\title{
Stock Returns and Mutual Fund Flows in the Korean Financial Market: A System Approach
}

\author{
Jaebeom Kim*, Jung-Min Kim**
}

The views expressed herein are those of the authors and do not necessarily reflect the official views of the Bank of Korea. When reporting or citing this paper, the authors' names should always be explicitly stated.

\footnotetext{
* Professor, Department of Economics, Oklahoma State University, E-mail: jb.kim@okstate.edu.

** Assistant Professor of Finance, University of Seoul, E-mail: kimjm2016@uos.ac.kr.
}

The authors are grateful for helpful comments from Moon Jung Choi, Woon Gyu Choi, Jong Ku Kang, Geun-Young Kim, Jaerang Lee, Jin-Su Park, and Joon Myung Woo. The first author is grateful for the financial support from the Bank of Korea; however, the views expressed herein are those of the authors and do not necessarily reflect those of the Bank of Korea. We would also like to thank Jin Woong Lee for his outstanding research support. 


\section{Contents}

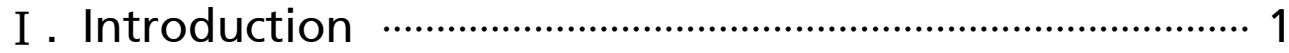

II . Korean Mutual Fund Industry …................................... 5

III. Econometric Methodologies …………………………..... 6

IV. Data and Empirical Results ………............................ 8

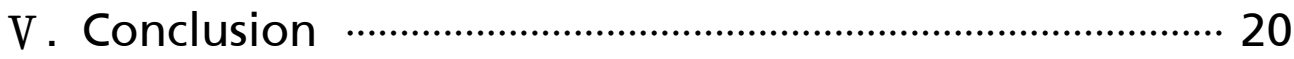

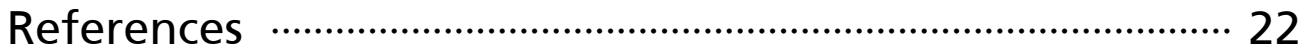




\section{Stock Returns and Mutual Fund Flows in the Korean Financial Market: A System Approach}

This paper investigates dynamic and causal relations between stock returns and mutual fund flows in Korea using a system method which utilizes information from the stock, bond, and money markets. For this purpose, we employ DSUR proposed by Mark, Ogaki, and Sul (2005), SURECM, and two causality tests by Granger (1969) and Sims (1972) in a system method to account for cross equation correlations among markets which have a close relationship with one another. Furthermore, we make use of information in the variance-covariance matrix of residual to improve the efficiency of the statistical estimates. The empirical evidence from the system method indicates that fund flows do not respond to eliminate the deviation from long-run equilibrium, and stock prices cause net fund flows in the Korean market, implying that investors move their money to the securities that yield higher returns to rebalance their investment portfolios in the short-run. Thus, our findings do not support the popular notion that considers mutual fund flows as a driving force behind rallies in Korean financial markets.

Keywords: Stock returns, Mutual fund flows, Causality, Co-integration, DSUR, SURECM

JEL classification: G11, C32 


\section{I . Introduction}

This paper studies the long-run and short-run dynamics and the possibility of a causality between stock returns and mutual fund flows in the Korean financial market using a system method. The degree to which prior stock market returns influence investor demand for mutual fund shares and to which this demand drives returns has important implications for the stability of the Korean stock market. Substantial efforts have been made to detect the relationships explained by security returns and mutual fund flows of the U.S. market. However the Korean mutual fund market, which is one of the most advanced and largest mutual fund industries in the world, has not been extensively researched. Therefore, in Korea, relatively little information is known on the behavior of cash flows of mutual funds and its relation to security returns in the market. While mutual funds have grown to become a dominant vehicle for savings in the U.S. over the past decade, the Korean mutual funds market has grown at a more modest pace. It is our interest to see whether the fund flows have been a driving factor of equity returns in the Korean financial market.

There are two distinctive approaches in analyzing the relations between stock returns and mutual fund flows: a micro approach and a macro approach. The former focuses on how mutual funds flows are analyzed on individual bases. Among the studies using the micro approach, Ippolito (1992), Hendricks et al. (1993), Grinblatt et al. (1995), and Sirri and Tufano (1998) show that investors tend to move cash into the funds that had the highest returns in the preceding years and find little support for the assumption that flows drive performance. On the other hand, the macro approach analyzes large scale movements of money into and out of the market without regard to any fund it goes into or comes from. Hence, the research at the macro level has centered on the relationship between stock market returns and aggregate mutual fund flows and can be broadly divided into two groups. Among the studies that belong to the first group, Warther (1995) investigates the relationships between the security returns and aggregate mutual fund cash flows. His results support the popular belief that fund inflows and returns are positively related. Remolona, Kleiman, and Gruenstein (1997) 
examine the effects of returns on fund flows and find that net flows into the various mutual fund groups are highly correlated with market performance. Edelen and Warner (2001), and Goetzmann and Massa (2003) discover that short-term fluctuation in aggregate investor demand for stocks are correlated to contemporaneous price changes and thus may move security prices. Boyer and Zheng (2009) find that the quarterly contemporaneous relations between mutual fund flows and returns are positive and significant. Their findings suggest that mutual fund sectors may exert price pressure on the market through their demand for stocks. Furthermore, the positive correlation between aggregate mutual fund flows and stock returns is supported by theoretical approaches such as the price pressure theory, information revelation hypothesis, and investor sentiment. ${ }^{1)}$

The other group of studies, however, finds little support for the assumption that flows drive performance. Fortune (1998) finds evidence that security returns affect future fund flows. Potter and Schneeweis (1998) report evidence that security returns are useful in predicting flows into aggressive growth funds and growth funds. Edwards and Zhang (1998) report that flows into stock and bond funds have not affected either stock or bond returns. In contrast, the magnitude of flows into both stock and bond funds are affected significantly by stock and bond returns. Fant (1999) provides evidence of feedback from returns to exchanges-out, as well as instantaneous feedback (with unknown direction) in a given month between returns and exchanges-in and -out. Cha and Lee (2001) contradict Edelen and Warner (2001) with regards to positive feedback. Their study cannot detect the price pressure effect, or the ability of fund flows to move stock returns. Cha and Kim (2010) employ a system method including an error correction model and the Granger causality test for the interactions between stock

1) Price pressure theory implies that when inflows in mutual funds increase, this stimulates a demand to hold stocks, and causes stock prices to go up. Information revelation hypothesis shows that based on the assumption that the market is to react to available information, well-informed investors' purchases may signal to other less-informed investors to buy mutual fund, thus cause stock prices to rise. Investor sentiment is also considered as one of the important factors affecting mutual fund market. See Warther (1995), Engen and Lehnert (2000), Boyer and Zheng (2009), and Braverman, et al. (2005) for details. 
returns and aggregate mutual fund flows. They find that stock returns lead stock fund flows in the U.S. financial market. Some recent papers argue that investor sentiments are important factors in overall market movements. Goetzmann, Massa and Rouwenhorst (2000) find evidence that is consistent with the existence of a pervasive investor sentiment variable. Goetzmann and Massa (2003) extract behavioral factors from individual investors' flows in S\&P 500 index mutual fund and test their incremental explanatory power using a classic asset-pricing model. Indro (2004) finds that the behavior of equity fund investors is influenced not only by economic fundamentals, but also by investor sentiment. Frazzini and Lamont (2008) use mutual fund flows as a measure for individual investor sentiment for different stocks, finding that high sentiment predicts low future returns at long horizons. Braverman, Kandel, and Wohl (2005) find the negative relationship between mutual fund flows and the subsequent returns. Using Korean mutual fund data, Oh and Parwada (2007) find that it is returns that drive flows, while stock sales may contain information about returns.

As can be seen, however, the results of the previous studies are mixed and the high positive correlation between fund flows and stock returns does not necessarily imply that the former causes the latter and vice versa because there might be other possible reasons for the causal relationship. Moreover, it is not clear whether the stock market is driven by mutual fund inflows and outflows due to the fact that prior studies on stock returns and mutual fund flows employ overly simple regression approaches such as least squares methodologies with logged differenced or normalized data, which removes the unit root or permanent component of the data and therefore avoids the complications related to unit roots and spurious regressions. In other words, an issue in estimating the long-run dynamics is that stock rates of return and net fund flows are calculated using first differences of stock returns and aggregate fund flows, respectively, which eliminates long-run information crucial to its measurement. As shown by Hendry (1986), Granger (1986), and Engle and Granger (1987), when a time series is differenced, long run information contained in the levels of the variables is lost and first-differenced variables which are integrated of order zero, $\mathrm{I}(0)$, such as 
stock returns and first differenced aggregate fund flows have only limited memory of past behaviors. On the other hands, variables that are integrated of order one, I(1), such as levels of stock prices and net fund flows, have an infinitely long memory. In this regard, many researchers should admit that their findings show only short-run dynamics. Since business cycle activity comprises both temporary and permanent components, the removal of the permanent component loses valuable long term information concerning the evolvement of short-term movements.

To examine whether the monthly net fund flows have been a driving factor of equity market returns in the recent increase of the Korean market, we employ a Dynamic Seemingly Unrelated Regression (DSUR) proposed by Mark, Ogaki, and Sul (2005), a Seemingly Unrelated Regression Error Correction Model (SURECM), and two causality tests suggested by Granger (1969) and Sims (1972) in a system method. Mutual fund is an investment vehicle that is made up of a pool of funds in securities such as stocks, bonds, money market instruments and similar assets. Those assets and their fund flows are directly related with each other. More specifically, when funds and their markets have a close relationship with one another, a seemingly unrelated regression methodology is presented to account for cross equation correlations among markets. Furthermore, we make use of information in the variance-covariance matrix of residual to improve the efficiency of the statistical estimates. This study is distinctive from the existing literature in employing the system method that utilizes information from the stock, bond, and money markets to improve the efficiency and provides more economically reasonable estimates.

Our empirical evidence from the system method shows unidirectional positive causality from stock prices to net fund flows. Furthermore, if there is a deviation from long-run equilibrium, the stock prices force the deviation to go toward the long-run equilibrium, implying that the mutual fund flows do not respond to eliminate the deviation from long-run equilibrium in the Korean financial market. 


\section{$5 \quad$ BOK Working Paper No. 2016-3}

\section{II . Korean Mutual Fund Industry}

Although the mutual fund industry in Korea has its regulatory origins in the late 1960s when the Securities Investment Trust Business Act (SITBA) introduced investment trusts similar to contractual type unit trusts found in the UK and Australia, the first equity investment was only introduced in 1970. The Korea Investment Trust Company (KITC), the first full-scale securities investment trust company specializing exclusively in mutual fund products, was established in 1974. According to a report released by the KOFIA, the ratios of both financial assets to GDP and the size of the capital market to GDP continued to grow in 2014, recording 4.2-fold and 0.9-fold growth, respectively. Between 2000 and 2014, the value of financial assets and the market capitalization increased by 4.2 times and 6.2 times, respectively, while the GDP grew 2.5 times. It shows that the growth of the financial industry has been accelerating, with the growth of financial assets and the capital market outpacing that of GDP. Assets held in Korean mutual funds have outstripped the nation's Gross Domestic Product since 1998, and now represent about half the stock market capitalization. ${ }^{2)}$

As Khorana et al. (2005) show, Korea with France rank second among countries with the highest number of mutual fund offerings after the U.S. However, according to the EFAMA report, the mutual fund industry in Korea manages the largest number of mutual funds, but their sizes are smaller compared to those under management in overseas countries. The number of investment funds under operation came to 11,063 at the end of Q4 in 2014, topping the 47 countries worldwide. But Korean funds' total assets averaged $\$ 28.2$ million at the end of September 2013, ranking 14th among the surveyed countries. Luxembourg held the second-largest number of funds at 9,839, but their average total asset stood at $\$ 3.3$ trillion. Brazil and the U.S. each held 8,560 funds and 7,923 funds, with their total net asset at $\$ 989$ billion and $\$ 15.8$ trillion, respectively, according to the data. ${ }^{3)}$

2) See the KOFIA report (2014) for details.

3) See the EFAMA report (2014) for details. 


\section{III . Econometric Methodologies}

We employ the Dynamic SUR (DSUR) proposed by Mark, Ogaki, and Sul (2005) to estimate the long run relationship between stock prices and fund flows. We make use of information in the variance-covariance matrix of residuals to improve the efficiency of the statistical estimates. Mark, Ogaki, and Sul (2005) propose a panel DSUR method for the estimation of co-integrating vector and it extends the parametric method and applies the SUR to multiple-equation co-integrating regressions to obtain asymptotically efficient estimators. The DSUR method is applied to the following equation over $\left.i(i=1,2,3)^{4}\right)$

$$
Y_{i t}=\alpha_{i}+\beta_{i} X_{i t-1}+\sum_{i=1}^{3} \sum_{j=-p}^{p} \theta_{i j} \Delta X_{i t-j}+\varepsilon_{i t}
$$

where $y_{i t}$ and $x_{i t}$ are equity prices and net fund flows in the Korean financial market, respectively and $p$ is the number of lead and lagged differences of all equations in the system account for possible serial correlation and endogeneity of the errors. In addition, the Dynamic OLS (DOLS), which extends the single equation DOLS technique of Saikkonen (1991) and Stock and Watson (1993) method, is estimated by:

$$
Y_{i t}=\alpha_{i}+\beta_{i} X_{i t-1}+\sum_{j=-p}^{p} \theta_{i j} \Delta X_{i t-j}+\varepsilon_{i t}
$$

As can be seen in this equation, the dynamic SUR is different from the DOLS as endogeneity in the equation is corrected by incorporating leads and lags of the first difference not only of the regressors of equation $\mathrm{i}$ but also of the regressors of all other equations in the system. We employ a two-step dynamic SUR method in Equation (1). In the first step, the regressand in each equation is regressed on the leads and lags of the first difference of the regressors from all equations to control for the endogeneity problem. In the second step, the SUR method is applied to the residuals from the first step regressions. The dynamic SUR estimator

4) $i$ represents stock, bond, and money markets. 
achieves asymptotic efficiency gains over the DOLS by incorporating the long-run cross sectional correlation in the equilibrium errors in estimation. In Equation (1), we assume that the cross sectional correlation is a stationary random variable, and $y_{i t}$ and $x_{i t}$ are stationary but have autoregressive roots near one. In that case, the point estimates can still be expected to be fairly precise and we can obtain more efficient co-integrating estimators than the OLS because these estimators are asymptotically consistent and have smaller biases than the OLS.

To investigate short run dynamics based on the Granger representation theorem, we consider an ECM under the assumption that $Z_{t}=Y_{t}-X_{t}^{\prime} \Upsilon$ is stationary:

$$
\begin{aligned}
& \Delta Y_{i t}=\mu_{0 i}+\lambda_{0 i} \hat{Z}_{i t-1}+\sum_{j=1}^{k} \delta_{1, i j} \Delta X_{i t-j}+\sum_{j=1}^{k} \delta_{2, i j} \Delta X_{i t-j}+u_{1, i t} \\
& \Delta X_{i t}=\mu_{1 i}+\lambda_{1 i} \hat{Z}_{i t-1}+\sum_{j=1}^{k} \varphi_{1, i j} \Delta X_{i t-j}+\sum_{j=1}^{k} \varphi_{2, i j} \Delta Y_{i t-j}+u_{2, i t}
\end{aligned}
$$

Equations (3) and (4) imply that security prices and cash flows are co-integrated with the co-integrating vector $(1,-\gamma)$ and assume that the long-run relationship between the two variables should be unique, but the short-run relationship between the markets may vary according to government policies, regulations, transaction costs, and the like. The SUR is applied to Equations (3) and (4) over $i(i=1,2,3)$. Under the assumption that $Z_{t}=Y_{t}-X_{t}^{\prime} \gamma$ is stationary, Equations (3) and (4) have exactly the same explanatory variables. In this case there is no efficiency gain for the SUR even when there is a perfect correlation between $u_{1, i t}$ and $u_{2, i t}$. However, an efficiency gain can be obtained over cross-sectional units. As long as $\Delta y_{1 t}, \Delta y_{2 t}$, and $\Delta y_{3 t}$ are highly correlated each other, an efficiency gain is possible. The point estimates of $\lambda$ have important economic contents. First, the stationarity of $\hat{Z}_{t}$ requires $\lambda_{0 i} \leq 0$ and $\lambda_{1 i} \geq 0$. Second, the weak exogeneity of $X_{t}$ with respect to the long run parameters requires $\lambda_{1 i}=0$, so the deviation from the long run equilibrium, $\hat{Z}_{t}$, does not affect $X_{t}$. Third, the point estimates of $\lambda_{0 i}$ measure the speed of adjustment to the long run equilibrium. 
For the hypothesis of causal relationships between security returns and investment trust flows, we adopt the notion of Granger causality (1969). Various researchers have used one of the two asymptotically equivalent test procedures attributed to Granger (1969) and Sims (1972) for testing the null hypothesis of unidirectional causality against the alternative of feedback. The Granger (1969) causality test is basically a test of the predictability of time-series models and means that if $X_{t}$ Granger-causes $Y_{t}$, then $X_{t}$ is a useful predictor of $Y_{t}$, given the other variables are controlled in the regression of the forms in equations (3) and (4). On the other hand, the Sims (1972) procedure is to run a regression of the form:

$$
Y_{t}=\delta_{0}+\sum_{i=-m}^{m} \theta_{i} X_{t-i}+\eta_{t}
$$

Sims proved that in the distributed lag regression, $\theta_{i}=0$ for all $i<0$ if, and only if, $Y$ fails to Granger-cause $X$.

\section{IV . Data and Empirical Results}

To examine whether aggregate fund flows drive security prices in the Korean financial market, data on fund flows and the corresponding security prices are required. Since mutual fund is an investment vehicle made up of a pool of funds in securities such as stocks, bonds, money market instruments, and similar assets and the assets and their fund flows are closely related with each other, we combine information of the stock market with information of the bond and money markets. Aggregate fund flows are collected from two complementing sources: (1) the EPFR Global database and (2) the Balance of Payments (BOP) data compiled and reported by the Bank of Korea (BOK).5) The EPFR database tracks both traditional and alternative funds domiciled globally with $\$ 24$ trillion in total

5) Since monthly aggregate fund flows are available in both datasets, we choose monthly as a time frequency for comparing the results between the two data sources and they are seasonally unadjusted. 
assets. Based on the EPFR database, we employ monthly aggregate fund flows, stock prices, and bond yields from January 2004 to August 2015. In this study, we focus on global fund flows investing in Korean stocks and bonds. The EPFR database provides not only country-level fund flows for stocks and bonds as a dollar amount but also the aggregate fund flows as a percentage value, which accounts for the effects of both a change in security price and a change in foreign exchange rate on assets under management. The EPFR database also reports the estimated assets under the management of stocks and bonds at the country level. The prior studies using the EPFR database show that the database captures only 5-20\% of the market capitalization in both stocks and bonds for most countries.

To complement the small coverage of the EPFR database in the global financial market, we also use the BOP data reporting the amount of foreign capital invested in stocks, long-term bonds and short-term bonds in Korea. For aggregate fund flows from the BOP data, we expand the sample period from January 2000 to August 2015. For better understanding of the coverage of the EPFR database, an example regarding the Korean stock market is given as follows: The EPFR database reports that the estimated assets under the management of Korean stocks are $\$ 124,469$ million as of August 2015. In the same month, the market value of stocks listed in the Korean stock exchange is about $\$ 1,025,523$ million. Hence, the coverage of the EPFR database for Korean stocks is $12.14 \%$, which is consistent with the range reported in the previous studies. Although we confirm that the EPFR database covers a small fraction of the financial market in Korea, the prior studies also point out that there is a close match between EPFR portfolio flows and portfolio flows stemming from the total BOP data (e.g., Jotikasthira et al. (2012), Fratzscher (2012)). As for security prices, we use KOSPI, 3-year and 5-year Government bonds6), and 3-month (91-days) Certificate of

6) Accoding to the Global Financial Stability Report by IMF, the EPFR data include bond funds that hold bonds with a wide range of maturities. Therefore, the effect of short-term rates on bond flows is obscured by possible differing effects on long-term bonds. The converse appears also to be true, as using long-term rates in the regressions does not change the results. Thus, whereas different interest rates along the yield curve may affect flows into bonds of different maturities, their effect on total flows into bonds of all maturities is not statistically significant in these data. 


\section{Table 1: Summary Statistics}

\begin{tabular}{cccccc} 
& Mean & Std. Error & Min & Max \\
\hline $\operatorname{In}($ KOSPI $)$ & 7.143 & 0.456 & 6.173 & 7.692 \\
$\ln ($ TB3 $)$ & 1.421 & 0.351 & 0.501 & 2.227 \\
$\operatorname{In}($ TB5 $)$ & 1.488 & 0.341 & 0.613 & 2.304 \\
$\operatorname{In}($ MMI) & 1.322 & 0.347 & 0.470 & 1.985 \\
SCF & 179.510 & 2630.597 & -10498.800 & 8429.000 \\
BCF & 454.531 & 1436.992 & -3715.500 & 6702.900 \\
MCF & 107.517 & 711.536 & -3037.200 & 2953.100 \\
SCF_MF & 258.645 & 919.209 & -2243.050 & 3053.160 \\
BCF_MF & 58.412 & 183.229 & -734.440 & 567.330 \\
\hline
\end{tabular}

Note: KOSPI: KOSPI stock average index. TB3 and TB5: Korean 3- and 5-year government bond index. MMI: Korean CD index. SCF: Korean stock aggregate fund flow from the BOK. BCF: Korean bond aggregate fund flow from the BOK. MCF: Korean money market fund flow from BOK. SCF_MF: Korean stock mutual fund net cash flow from the EPFR. BCF_MF: Korean bond mutual fund net cash flow from the EPFR.

Deposit (CD) for stock, bond, and money markets, respectively. Their returns or yields are measured at a monthly frequency from January 2000 to August 2015. The data is obtained from the BOK Economic Statistics System.

Table 1 shows descriptive statistics for variables we employ in this paper. To gain more insight into the relationship between mutual fund flows and security market returns, we employ various tests and further examine the relationship. For a possible co-movement or a contemporaneous relationship between security market returns and mutual fund flows, we present figures of the variables of the model in levels and first differences. These figures exhibit contemporaneous relations and positive relationships over time between the two variables. 


\section{$11 \quad$ BOK Working Paper No. 2016-3}

Figure 1: Time-Series Plots in the Korean Stock Market

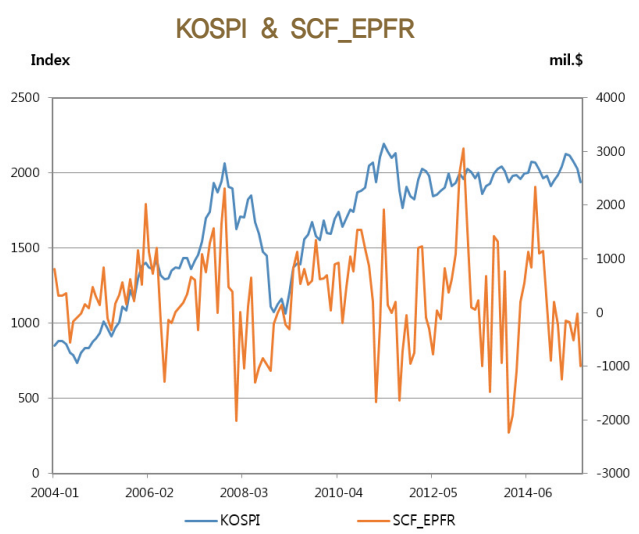

Diff(KOSPI \& SCF_EPFR)

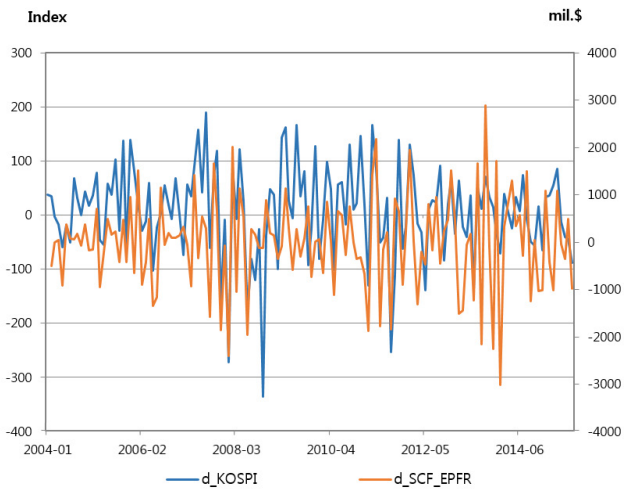

KOSPI \& SCF BOK

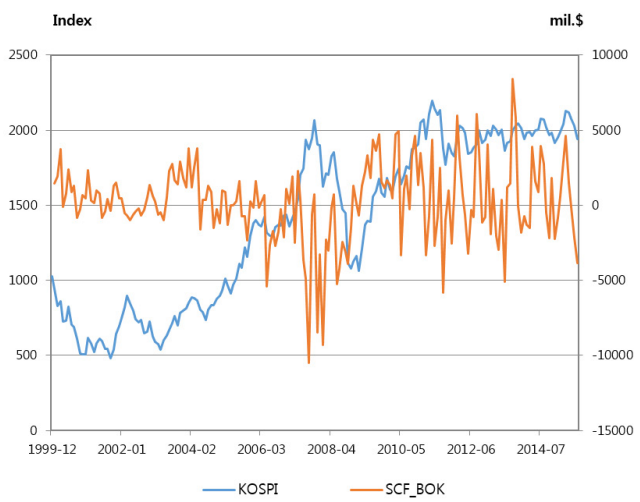

Diff(KOSPI \& SCF_BOK)

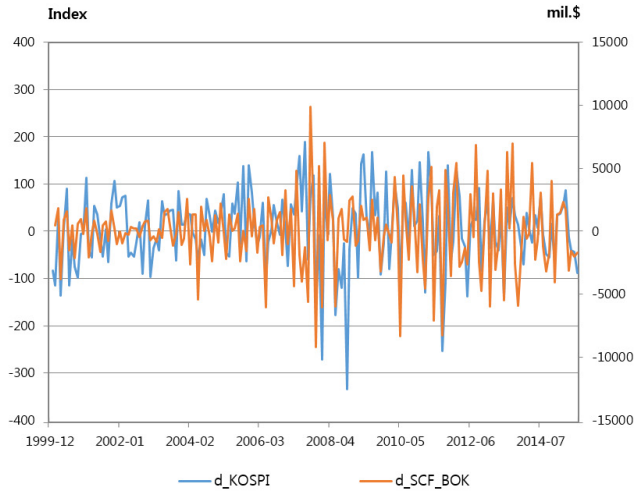


Figure 2: Time-Series Plots in the Korean Bond and Money Market

Yields \& Bondflow_BOK

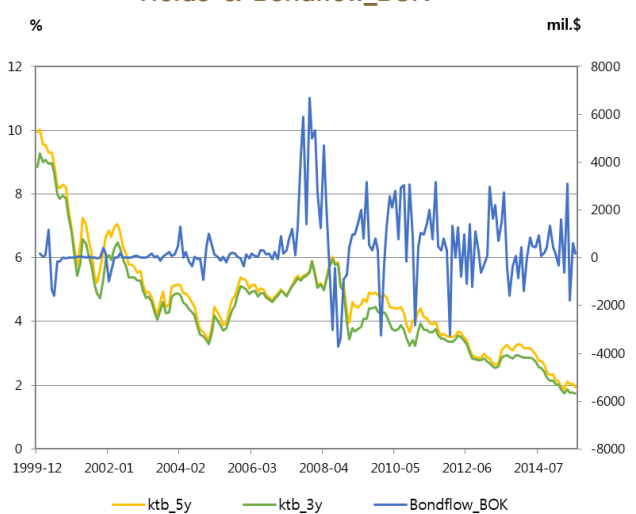

Yields \& Bondflow_EPFR

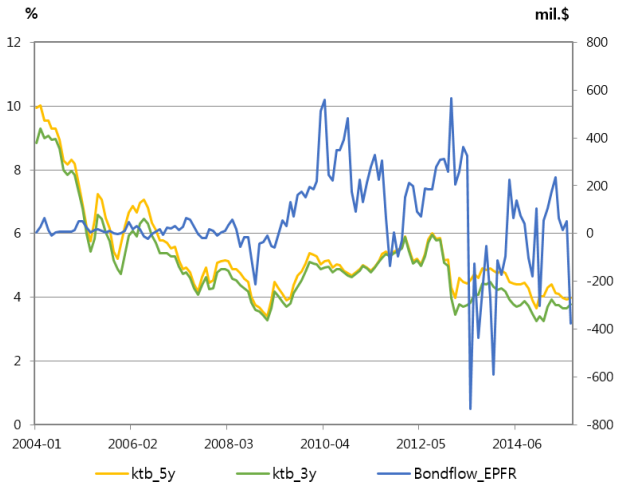

CD Yield \& MMF

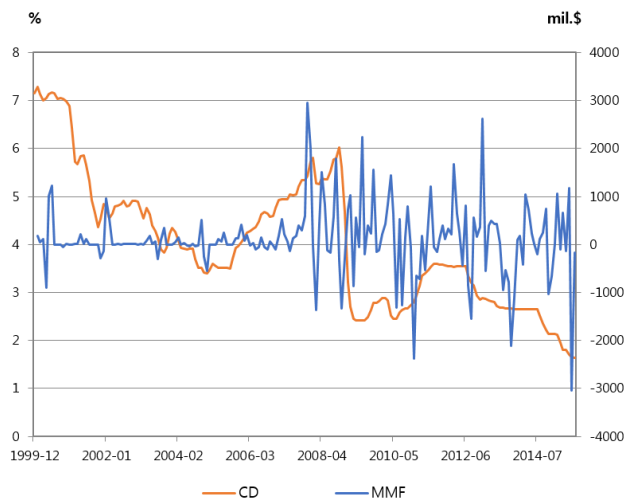

Diff(Yields \& Bondflow_BOK)

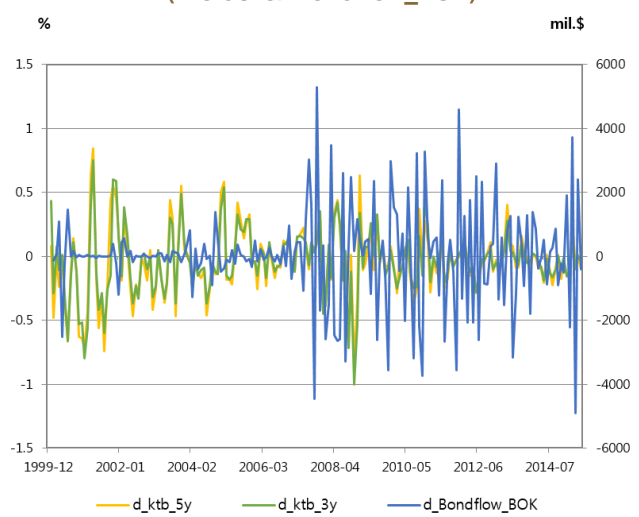

Diff(Yields \& Bondflow_EPFR)

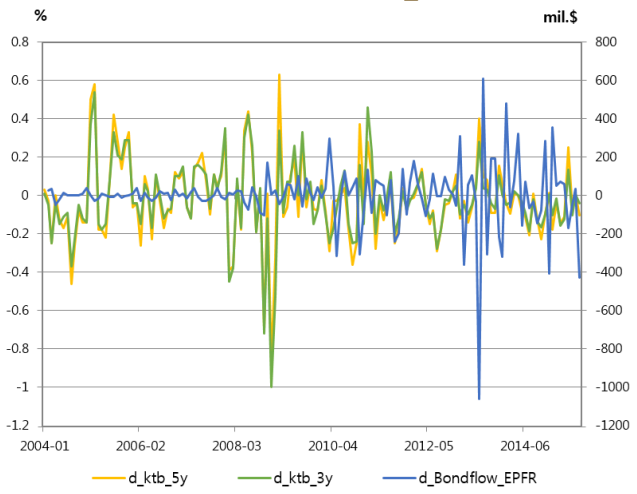

Diff(CD Yield \& MMF)

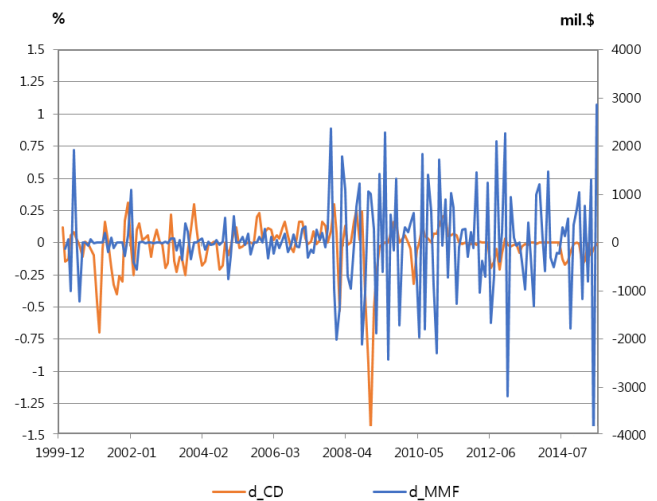


Table 2: Unit Root Tests for Stock Price and Aggregate Fund Flows

\begin{tabular}{c|c|c} 
& ADF test & KPSS test \\
$t_{\rho=1}$ & $\eta_{\mu}$ \\
$\ln ($ KOSPI $)$ & -1.365 & $1.596^{* *}$ \\
$\ln ($ TB3 $)$ & -0.385 & $1.442^{* *}$ \\
$\ln ($ TB5 $)$ & -0.274 & $1.423^{* *}$ \\
$\ln (\mathrm{MMI})$ & -1.038 & $1.271^{* *}$ \\
SCF & $-3.176^{* *}$ & 0.134 \\
BCF & $-3.291^{* *}$ & 0.251 \\
MCF & $-3.418^{* *}$ & 0.125 \\
SCF_MF & $-3.125^{* *}$ & 0.165 \\
BCF_MF & -1.614 & 0.159 \\
\hline
\end{tabular}

Note: ** and * represent denote significance at the $5 \%$ and $10 \%$ levels, respectively. The Critical values for t-statistic are -2.88 and -2.57 for $5 \%$ and $10 \%$ significant levels, respectively. For KPSS tests, the critical values are 0.463 , and 0.347 for $5 \%$, and $10 \%$ levels of significance, respectively. KOSPI: KOSPI stock average index. TB3 and TB5: Korean 3- and 5-year government bond index. MMI: Korean CD index. SCF: Korean stock aggregate fund flow from the BOK. BCF: Korean bond aggregate fund flow from the BOK. MCF: Korean money market fund flow from BOK. SCF_MF: Korean stock mutual fund net cash flow from the EPFR. BCF_MF: Korean bond mutual fund net cash flow from the EPFR.

Table 2 shows the results of unit root tests based on the ADF and the KPSS tests.7) According to the ADF and the KPSS tests, all security prices and most aggregate fund flows in the mutual funds are nonstationary at the $5 \%$ significance level with the exception of international mutual fund flows in stock, bond, and money market. It is likely that they are stationary with near unit root. In that case, as shown by Elliot (1998), the estimators assuming unit root can still be good estimators even though sometimes reported standard errors are likely to be inaccurate. He also shows that it would be better to use efficient co-integrating estimators than the ordinary method because these estimators would be asymptotically consistent and have smaller biases than the ordinary method.8)

7) For maximum lags, we use Hall's general to specific method.

8) See Elliot (1998) for details. 
Table 3: Co-integration and Correlations for Stock Price and Aggregate Fund Flows

\begin{tabular}{|c|c|c|c|c|c|c|c|c|c|}
\hline \multirow[b]{3}{*}{ SCF } & \multirow[b]{3}{*}{$\ln (\mathrm{KOSPI})$} & \multirow{2}{*}{\multicolumn{2}{|c|}{ DOLS }} & \multicolumn{3}{|c|}{ DSUR } & \multicolumn{3}{|c|}{ DSUR } \\
\hline & & & & \multicolumn{2}{|c|}{$\beta$} & \multirow{2}{*}{$\begin{array}{l}\text { Cl Test } \\
-9.662^{* *}\end{array}$} & \multicolumn{2}{|r|}{$\beta$} & \multirow{2}{*}{$\begin{array}{l}\mathrm{Cl} \text { Test } \\
-9.538^{* *}\end{array}$} \\
\hline & & 39.197 & (443.138) & $909.117^{* * *}$ & (380.351) & & \multirow[t]{2}{*}{$821.372^{* *}$} & \multirow{2}{*}{ (377.599) } & \\
\hline $\mathrm{BCF}$ & $\ln (\mathrm{TB} 3)$ & -181.360 & $(409.936)$ & 43.769 & (331.088) & -2.325 & & & $-9.538^{* *}$ \\
\hline $\mathrm{BCF}$ & $\ln ($ TB5) & -111.391 & (451.111) & & & & 56.360 & (332.721) & -2.474 \\
\hline MCF & $\ln (\mathrm{MMI})$ & 244.522 & $(240.057)$ & 148.891 & (189.719) & -2.949 & 192.623 & $(198.894)$ & -2.990 \\
\hline SCF_MF & $\ln ($ KOSPI) & $677.533^{* *}$ & (267.539) & $771.317^{* *}$ & $(345.262)$ & $-9.301^{* *}$ & $719.304^{*}$ & $(364.044)$ & $-6.281^{* *}$ \\
\hline BCF_MF & $\ln (\mathrm{TB} 3)$ & 80.224 & $(115.572)$ & $108.426^{*}$ & $(64.750)$ & $-4.207^{* *}$ & & & \\
\hline BCF_MF & $\ln (\mathrm{TB} 5)$ & 65.989 & $(60.595)$ & & & & $112.658^{*}$ & (67.873) & $-4.358^{* *}$ \\
\hline MCF & $\ln (M M M)$ & 244.522 & $(240.057)$ & $1017.784^{* *}$ & (326.878) & -8.078 & $903.477^{*}$ & (334.628) & $-8.703^{* *}$ \\
\hline \multicolumn{10}{|c|}{ Correlation Matrix of Residuals } \\
\hline \multicolumn{10}{|c|}{ BOP Data } \\
\hline & & $\ln ($ KOSPI) & $\ln (\mathrm{TB} 5)$ & $\ln (\mathrm{MMI})$ & & & SCF & BCF & MCF \\
\hline & $\ln (\mathrm{KOSPI})$ & 1 & & & & SCF & 1 & & \\
\hline & $\ln ($ TB5) & -0.694 & 1 & & & $\mathrm{BCF}$ & -0.193 & 1 & \\
\hline & $\ln (\mathrm{MMI})$ & -0.697 & 0.849 & 1 & & MCF & -0.060 & 0.185 & 1 \\
\hline \multicolumn{10}{|c|}{ EPFR Data } \\
\hline & & $\ln (\mathrm{KOSPI})$ & $\ln (\mathrm{TB} 5)$ & $\ln (\mathrm{MMI})$ & & & SCF & BCF & MCF \\
\hline & $\ln (\mathrm{KOSPI})$ & 1 & & & & SCF_MF & 1 & & \\
\hline & $\ln (\mathrm{TB} 5)$ & -0.439 & 1 & & & BCF_MF & -0.737 & 1 & \\
\hline & $\ln (\mathrm{MMI})$ & -0.330 & 0.774 & 1 & & MCF & -0.201 & 0.115 & 1 \\
\hline
\end{tabular}

Note: ** and * represent denote significance at the $5 \%$ and $10 \%$ levels, respectively. The Critical values for $\mathrm{Cl}$ test from the Engle and Yoo (1987) are -3.37 and -3.03 at $5 \%$ and $10 \%$ levels, respectively.

Table 3 provides the estimation as well as test results of co-integrating vectors between equity prices and aggregate fund flows. For the test of co-integration, we employ the Engle-Granger methodology, which is a residual-based unit root test.9) As seen from the results in Table 3, the DSUR provides positive and significant estimates for co-integrating coefficient values especially for equity prices and aggregate fund flows in mutual fund markets, while the DOLS do not provide any economically meaningful and significant long run relationships between equity prices and fund flows. The empirical results show that there is a positive long-run relationship between stock prices and fund flows in the market and we reject the

9) We perform a ADF test on the residuals without intercepts from Equation (1) and use the critical values from Engle and Yoo (1987). The critical values for the test of cointegration are -3.37 and -3.03 at 5\% and $10 \%$ levels, respectively. 
Table 4: SURECM Results for Stock Price and Aggregate Fund Flows

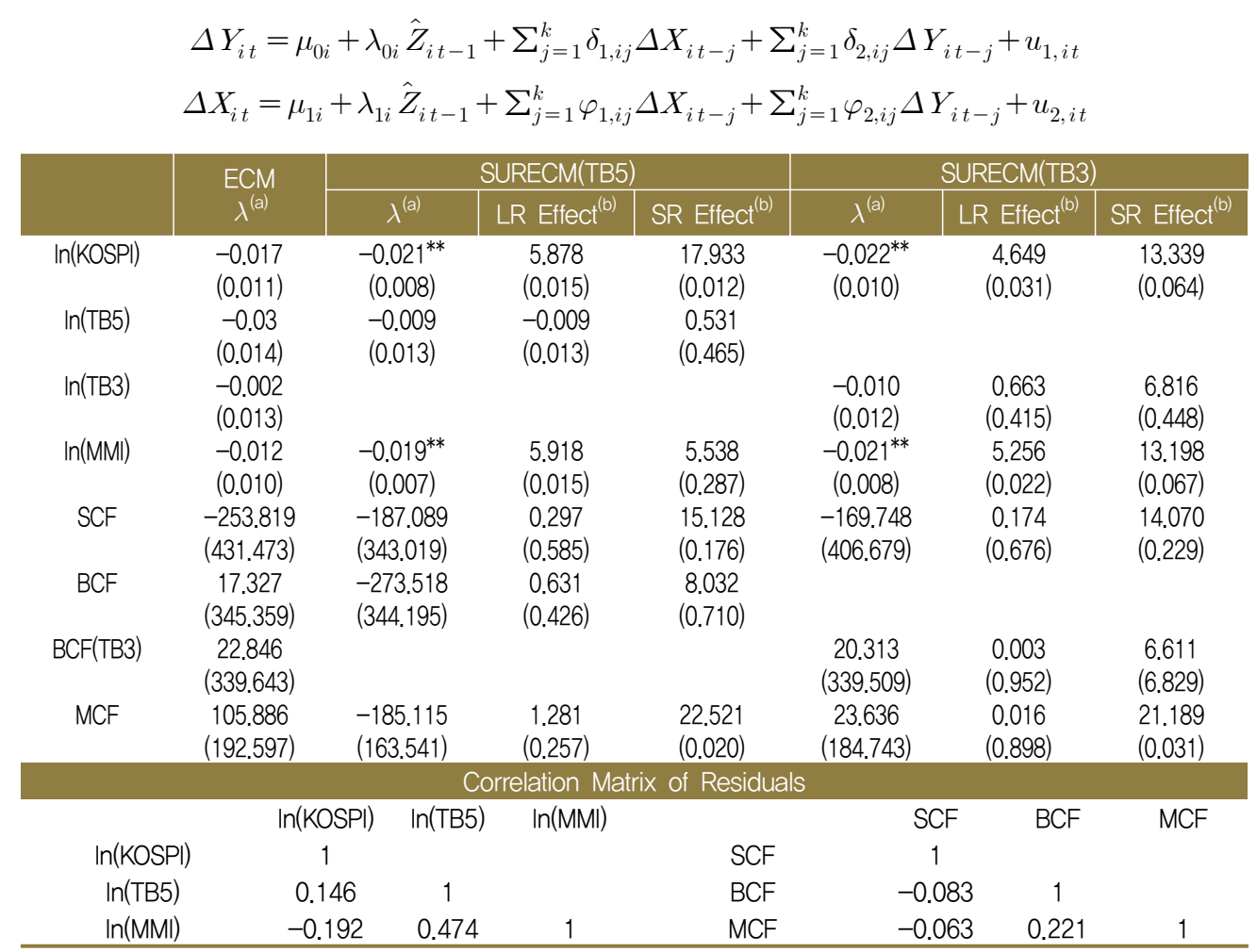

Note: * and ** denote significance at the $10 \%$ and $5 \%$ levels, respectively. Numbers in columns (a) represent standard errors and those in columns (b) represent p-values.

null of no co-integration, implying that the two variables move together in the long-run. This result is interesting because it seems to show that though stock prices are affected by short-run fluctuations of fund flows but eventually in the long run, both security prices and aggregate fund flows are correlated with economic fundamentals including investment, financial development, and stability of the financial markets. ${ }^{10)}$ In addition, there is no huge difference between 3-year and 5-year Government bonds in terms of sign and size of the estimates.

The results of the ordinary ECM as well as SURECM are reported in Tables 4 and 5 and the last two columns of the tables contain the F-statistics

10) This is the well-recognized observation in King and Levine (1993) and Levine (1997) regarding financial development and economic growth. 
Table 5: SURECM Results for Stock Price and Mutual Fund Flows

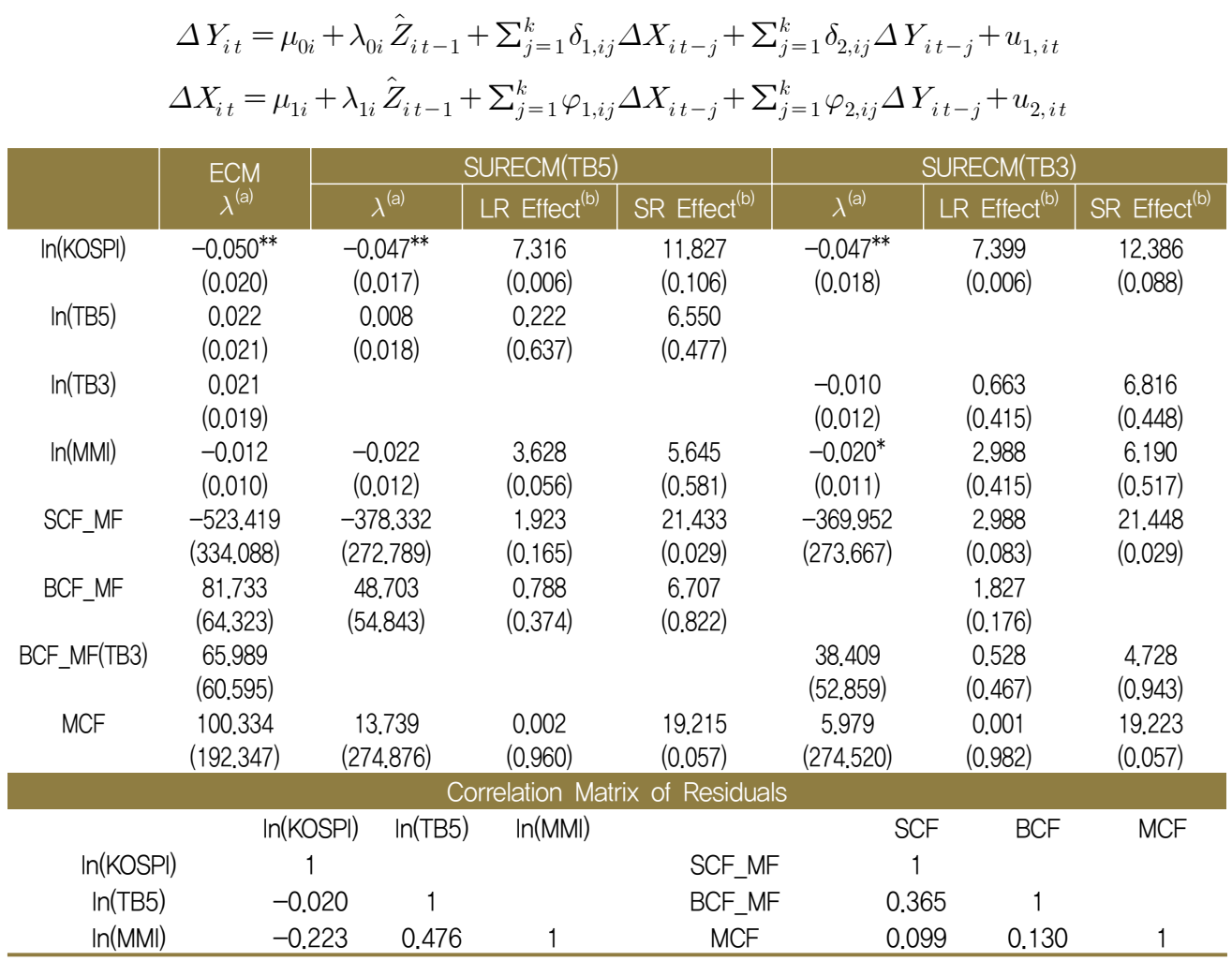

Note: * and ** denote significance at the $10 \%$ and $5 \%$ levels, respectively. Numbers in columns (a) represent standard errors and those in columns (b) represent p-values.

that test for long-run and short-run relations between security returns and net fund flows. First of all, comparing to the absolute values, standard errors, and the signs of $\lambda_{0 i} \mathrm{~s}$ and $\lambda_{1 i} \mathrm{~s}$, the SURECM provides larger and statistically more significant point estimates for changes in stock prices as well as money market returns than those of the ordinary ECM and shows theoretically meaningful signs for all security returns and net fund flows. Second, according to the results from the SURECM, the point estimates of all net fund flows are not significantly different from zero. This is strong evidence that the net fund flows do not respond to eliminate the deviation from long run equilibrium, implying that if there is a deviation from long-run equilibrium, the changes in stock prices and money market returns force the deviation to go toward the long-run equilibrium. In 
Table 6: Granger and Sims Causality Tests for Aggregate Fund Flows (TB5)

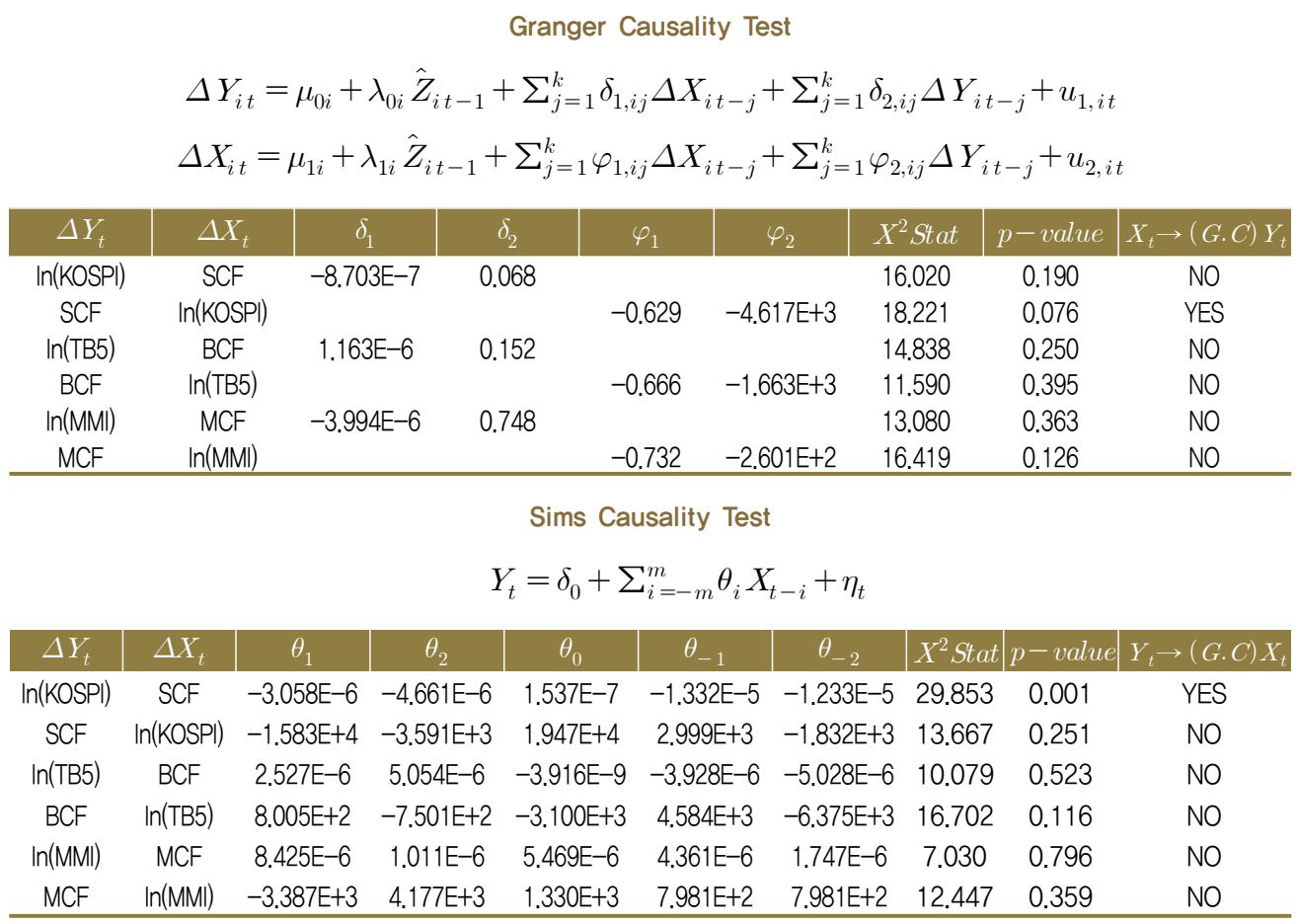

Note: "Yes (No)" indicates presence (absence) of causality with a $p$-value of equal or less than 0.1 .

addition, the hypothesis of neither long-run nor short-run relations between the two variables in the bond market is rejected at the $5 \%$ level. In effect, previous changes in stock prices and money market returns cause changes in cash flows in the stock and money markets in the same direction because of positive long-term effects. However, the same is not true for cash flows in those markets.

According to the Granger and Sims causality tests in Tables 6 through 9, in most cases we reject the null hypothesis, which implies that security returns lead net fund flows with the exception of bond market in which no causality exists based on both the Granger and Sims causality tests.11) The positive causality from security returns to net fund flows indicates that changes in the past and current returns cause changes in the current and next returns,

11) We test the causality hypothesis that stock returns (net equity fund flows) do not lead net fund flows (stock returns). 


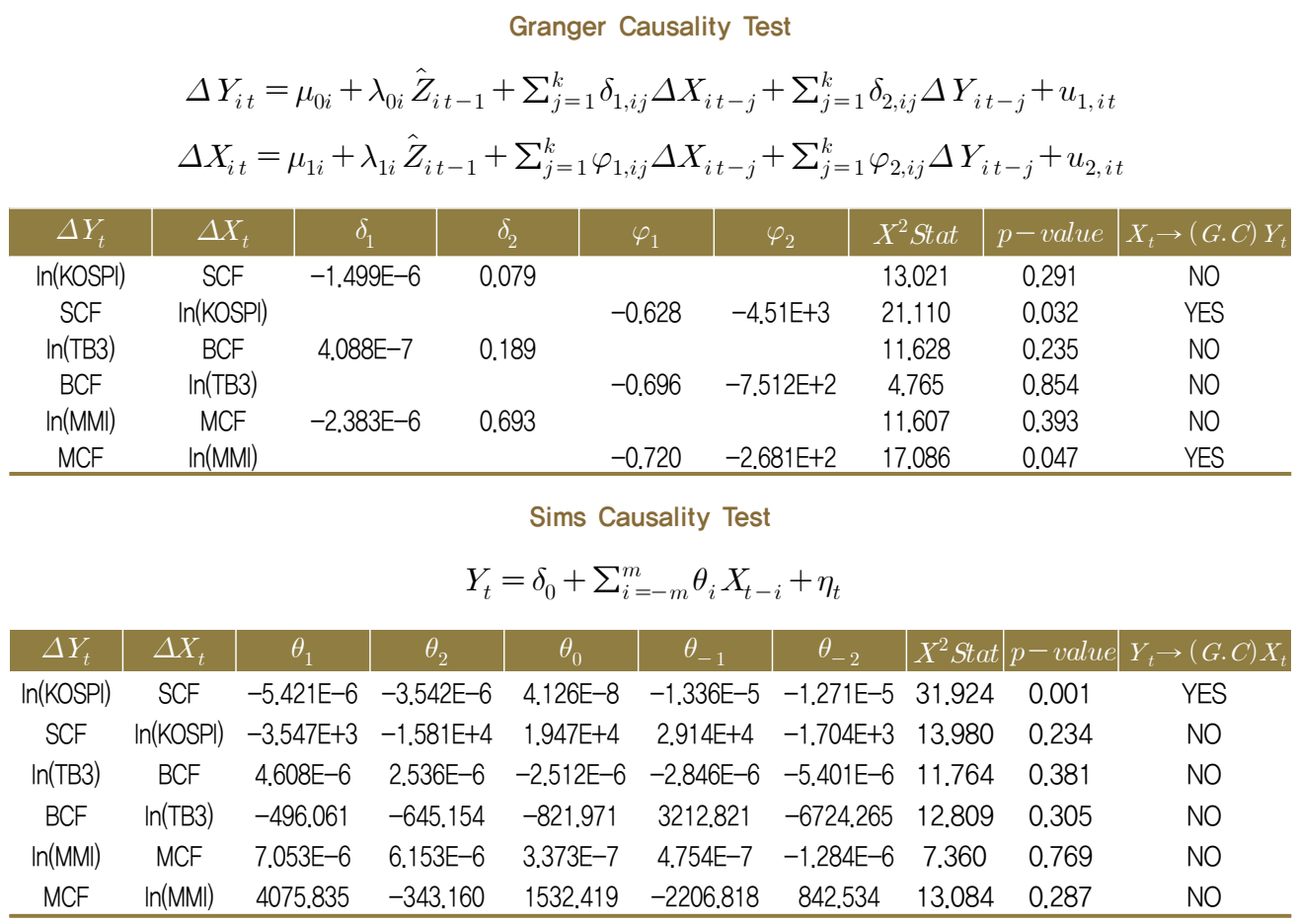

Note: "Yes (No)" indicates presence (absence) of causality with a $p$-value of equal or less than 0.1 .

resulting in changes in the current and next equity fund flows in the same direction. When security returns are used as dependent variables for the Granger causality test, we have the insignificant point estimates of $\hat{\delta}_{1}$ at the $5 \%$ level, implying that the stock market is not affected by monthly cash flows in the prior month. On the other hand, as mutual fund flows are used as dependent variables, the point estimates of $\hat{\varphi}_{2}$ are positive and statistically significant at the $5 \%$ level, showing that the net cash flows into the stock markets are affected by the returns in the previous month. This evidence is different from Warther (1995) who finds flows are negatively related to past returns. Moreover, as net fund flows are used as the dependent variables, we have a significant positive coefficient for the first lag, which is consistent with a feedback trader hypothesis. This evidence also contrasts with Warther (1995) who finds no evidence for the hypothesis. The Granger and Sims causality tests provide strong evidence that stock returns cause 
Table 8: Granger and Sims Causality Tests for Aggregate Mutual Fund Flows (TB5)

Granger Causality Test

$$
\begin{aligned}
& \Delta Y_{i t}=\mu_{0 i}+\lambda_{0 i} \hat{Z}_{i t-1}+\sum_{j=1}^{k} \delta_{1, i j} \Delta X_{i t-j}+\sum_{j=1}^{k} \delta_{2, i j} \Delta Y_{i t-j}+u_{1, i t} \\
& \Delta X_{i t}=\mu_{1 i}+\lambda_{1 i} \hat{Z}_{i t-1}+\sum_{j=1}^{k} \varphi_{1, i j} \Delta X_{i t-j}+\sum_{j=1}^{k} \varphi_{2, i j} \Delta Y_{i t-j}+u_{2, i t}
\end{aligned}
$$

\begin{tabular}{|c|c|c|c|c|c|c|c|c|}
\hline$\Delta Y_{t}$ & $\Delta X_{t}$ & $\delta_{1}$ & $\delta_{2}$ & $\varphi_{1}$ & $\varphi_{2}$ & $X^{2}$ Stat & $p$-value & $X_{t} \rightarrow(G . C) Y_{t}$ \\
\hline $\ln (\mathrm{KOSPI})$ & SCF_MF & $1.207 \mathrm{E}-6$ & -0.051 & & & 18.076 & 1.113 & NO \\
\hline SCF_MF & $\ln (\mathrm{KOSPI})$ & & & -0.051 & 238.876 & 18.283 & 0.075 & YES \\
\hline $\ln (\mathrm{TB} 5)$ & BCF_MF & $9.680 \mathrm{E}-6$ & 0.095 & & & 14.943 & 0.244 & NO \\
\hline BCF_MF & $\ln (\mathrm{TB} 5)$ & & & -0.489 & -151.755 & 6.471 & 0.840 & NO \\
\hline $\ln (M M I)$ & MCF & $-6.688 \mathrm{E}-6$ & 0.806 & & & 18.301 & 0.106 & NO \\
\hline MCF & $\ln (\mathrm{MMI})$ & & & -0.699 & 67.511 & 17.170 & 0.102 & NO \\
\hline
\end{tabular}

Sims Causality Test

$$
Y_{t}=\delta_{0}+\sum_{i=-m}^{m} \theta_{i} X_{t-i}+\eta_{t}
$$

\begin{tabular}{cccccccc|ccc}
$\Delta Y_{t}$ & $\Delta X_{t}$ & $\theta_{1}$ & $\theta_{2}$ & $\theta_{0}$ & $\theta_{-1}$ & $\theta_{-2}$ & $X^{2}$ Stat & $p-$ value $Y_{t} \rightarrow(G . C) X_{t}$ \\
In(KOSPI) & SCF_MF & $1.188 \mathrm{E}-5$ & $6.731 \mathrm{E}-6$ & $3.302 \mathrm{E}-5$ & $8.220 \mathrm{E}-7$ & $-2.885 \mathrm{E}-6$ & 21.849 & 0.025 & YES \\
SCF_MF & In(KOSPI) & $-3.054 \mathrm{E}+3$ & $-1.682 \mathrm{E}+3$ & $6.634 \mathrm{E}+3$ & 763.372 & 203.532 & 11.302 & 0.418 & NO \\
In(TB5) & BCF_MF & $-2.848 \mathrm{E}-5$ & $2.299 \mathrm{E}-5$ & $-8.817 \mathrm{E}-5$ & $6.112 \mathrm{E}-6$ & $4.424 \mathrm{E}-5$ & 8.850 & 0.635 & NO \\
BCF_MF & In(TB5) & 544.200 & 25.889 & -839.095 & 310.089 & -91.318 & 10.600 & 0.477 & NO \\
In(MMI) & MCF & $4.651 \mathrm{E}-6$ & $6.931 \mathrm{E}-6$ & $2.179 \mathrm{E}-6$ & $2.179 \mathrm{E}-6$ & $2.237 \mathrm{E}-6$ & 7.133 & 0.788 & NO \\
MCF & $\operatorname{In}(\mathrm{MMM})$ & $-5.63 \mathrm{E}+3$ & $4.963 \mathrm{E}+3$ & $-2.819 \mathrm{E}+3$ & $-2.819 \mathrm{E}+3$ & $1.769 \mathrm{E}+3$ & 8.922 & 0.629 & NO \\
\hline
\end{tabular}

Note: "Yes (No)" indicates presence (absence) of causality with a $p$-value of equal or less than 0.1 .

Table 9: Granger and Sims Causality Tests for Aggregate Mutual Fund Flows (TB3)

\begin{tabular}{|c|c|c|c|c|c|c|c|c|}
\hline$\Delta Y_{t}$ & $\Delta X_{t}$ & $\delta_{1}$ & $\delta_{2}$ & $\varphi_{1}$ & $\varphi_{2}$ & $X^{2}$ Stat & $p$-value & $X_{t} \rightarrow($ G.C $) Y_{t}$ \\
\hline $\ln ($ KOSPI) & SCF_MF & $2.131 \mathrm{E}-7$ & -0.042 & & & 12.796 & 1.163 & NO \\
\hline SCF_MF & $\ln (\mathrm{KOSPI})$ & & & -0.521 & 272.676 & 14.786 & 0.096 & YES \\
\hline $\ln \left(\mathrm{T}^{\mathrm{T}} \mathrm{B}\right)$ & BCF_MF & $6.886 \mathrm{E}-6$ & 0.052 & & & 6.645 & 0.827 & NO \\
\hline BCF_MF & $\ln (\overline{\mathrm{TB}} 3)$ & & & -0.473 & -26.529 & 2.196 & 0.987 & NO \\
\hline $\ln (M M)$ & MCF & $-5.917 \mathrm{E}-6$ & 0.747 & & & 13.638 & 0.253 & NO \\
\hline $\mathrm{MCF}$ & $\ln (\mathrm{MM})$ & & & -0.676 & -322.417 & 16.095 & 0.065 & YES \\
\hline
\end{tabular}
Granger Causality Test

$$
\begin{aligned}
& \Delta Y_{i t}=\mu_{0 i}+\lambda_{0 i} \hat{Z}_{i t-1}+\sum_{j=1}^{k} \delta_{1, i j} \Delta X_{i t-j}+\sum_{j=1}^{k} \delta_{2, i j} \Delta Y_{i t-j}+u_{1, i t} \\
& \Delta X_{i t}=\mu_{1 i}+\lambda_{1 i} \hat{Z}_{i t-1}+\sum_{j=1}^{k} \varphi_{1, i j} \Delta X_{i t-j}+\sum_{j=1}^{k} \varphi_{2, i j} \Delta Y_{i t-j}+u_{2, i t}
\end{aligned}
$$


Sims Causality Test

$$
Y_{t}=\delta_{0}+\sum_{i=-m}^{m} \theta_{i} X_{t-i}+\eta_{t}
$$

\begin{tabular}{cccccccc|ccc}
$\Delta Y_{t}$ & $\Delta X_{t}$ & $\theta_{1}$ & $\theta_{2}$ & $\theta_{0}$ & $\theta_{-1}$ & $\theta_{-2}$ & $X^{2}$ Stat & $p-$ value & $Y_{t} \rightarrow\left(\right.$ G.C) $X_{t}$ \\
In(KOSPI) & SCF_MF & $4.489 \mathrm{E}-6$ & $9.709 \mathrm{E}-6$ & $3.209 \mathrm{E}-5$ & $1.277 \mathrm{E}-8$ & $-5.908 \mathrm{E}-6$ & 24.984 & 0.009 & YES \\
SCF_MF & $\operatorname{In}($ KOSPI) & -1618.605 & -3052.579 & 6693.808 & 831.738 & 160.421 & 10.507 & 0.485 & NO \\
In(TB3) & BCF_MF & $3.087 \mathrm{E}-5$ & $-1.338 \mathrm{E}-5$ & $-6.762 \mathrm{E}-5$ & $3.708 \mathrm{E}-6$ & $3.232 \mathrm{E}-5$ & 10.514 & 0.484 & NO \\
BCF_MF & $\operatorname{In}(\mathrm{TB} 3)$ & 96.112 & 329.248 & -588.689 & 169.349 & -73.951 & 5.795 & 0.886 & NO \\
$\operatorname{In}(\mathrm{MMII})$ & $\mathrm{MCF}$ & $5.240 \mathrm{E}-6$ & $1.451 \mathrm{E}-6$ & $-1.558 \mathrm{E}-6$ & $9.863 \mathrm{E}-7$ & $-1.655 \mathrm{E}-6$ & 7.282 & 0.775 & NO \\
MCF & $\operatorname{In}(\mathrm{MMI})$ & 4791.727 & -5445.086 & 2768.766 & 2862.177 & 1629.566 & 8.987 & 0.623 & NO \\
\hline
\end{tabular}

Note: "Yes (No)" indicates presence (absence) of causality with a p-value of equal or less than 0.1 .

aggregate equity fund flows. These findings are interesting because as stock market performance increases, investors are likely to react to the level of the stock market and are encouraged to invest more in the market.

\section{V . Conclusion}

To investigate the dynamic and causal relations in a more efficient fashion between stock prices and mutual fund flows in the Korean mutual fund market at the macro level, this study employs a system method which combines information of the stock market with information of the bond and money markets because mutual fund is made up of a pool of funds in securities such as stocks, bonds, money market instruments and similar assets, and those assets and their fund flows are closely related with each other. For this purpose, we employ the DSUR proposed by Mark, Ogaki, and Sul (2005), the SURECM, and two causality tests suggested by Granger (1969) and Sims (1972) in a system method. Even though there is no standard way to interpret the empirical results, our findings based on the system method can be explained in several ways. The empirical evidence from the weak exogeneity of the net fund flows and the positive causality from stock returns to net mutual fund flows can be explained by the investor sentiment. Several empirical studies have shown the significance and the profound impact of the investor sentiment on the U.S. equity market. 


\section{$21 \quad$ BOK Working Paper No. 2016-3}

Our empirical findings are not likely to support the popular notion that considers mutual fund flows as a driving force behind rallies in the Korean mutual fund markets. Instead, the empirical evidence shows that at the aggregate level, investors react to securities performances at monthly frequency, and investors psychology or expectations lead to move their money to the securities that yield higher returns to rebalance their investment portfolios in the short-run. This type of behavior seems to be rational for those who try to maximize their individual returns. In addition, this investment strategy disciplines fund managers and aligns their interests with those of investors as well. Our empirical findings do not support the popular notion that sees mutual fund flows as a driving force behind rallies in security markets. The most important element explaining mutual fund flows seems to be security performance in the Korean financial market. 


\section{References}

Boyer, B., and L. Zheng (2009), "Investor Flows and Stock Market Returns," Journal of Empirical Finance, Vol. 16(1), pp. 87-100.

Braverman, O., S. Kandel, and A. Wohl (2005), "The (Bad?) Timing of Mutual Fund Investors," CEDR Discussion Paper No. 5243.

Campbell, J. Y., and P. Perron (1991), "Pitfalls and Opportunities: What Macroeconomists Should Know about Unit Roots," NBER Macroeconomics Annual, Vol. 6, pp. 141-220.

Cha, H. J., and B. S. Lee (2001), "The Market Demand Curve for Common Stocks: Evidence from Equity Mutual Fund Flows," Journal of Financial and Quantitative Analysis, Vol. 36(2), pp. 195-220.

Cha, H. J., and J. B. Kim (2010), "Stock Returns and Aggregate Mutual Fund Flows: A System Approach," Applied Financial Economics, Vol. 20(19), pp. 1493-1498.

Dickey, D. A., and W. A. Fuller (1979), "Distribution of the Estimators for Autoregressive Time Series with a Unit Root," Journal of the American Statistical Association, Vol. 74, pp. 427-431.

Edelen, R., and J. B. Warner (2001), "Aggregate Price Effects of Institutional Trading: A Study of Mutual Fund Flow and Market Returns," Journal of Financial Economics, Vol. 59(2), pp. 195-220.

EFAMA (2014), "Worldwide Investment Fund Assets and Flows: Trend in the Fourth Quarter 2014," European Fund and Asset Management Association.

Elliot, G. (1998), “On the Robustness of Cointegrating Methods When Regressors Almost Have Unit Roots," Econometrica, Vol. 66, pp. 149-158.

Engen, E., and A. Lehnert (2000), "Mutual Funds and the U.S. Equity Market," Federal Reserve Bulletin, Vol. 86, pp. 797-812.

Engle, R. F., and C. W. Granger (1987), "Co-Integration and Error Correction: Representation, Estimation, and Testing," Econometrica, Vol. 55(2), pp. 251-276. 
Engle, R. F., and B. S. Yoo (1987), "Forecasting and Testing in Co-Integrated System," Journal of Econometrics, Vol. 35(1), pp. 143-159.

Fant, L. F. (1999), "Investment Behavior of Mutual Fund Shareholders: The Evidence from Aggregate Fund Flows," Journal of Financial Markets, Vol. 2(4), pp. 391-402.

Fortune, P. (1998), "Mutual Funds, Part II: Fund Flows and Security Returns," New England Economic Review, pp. 3-22.

Fratzscher, M. (2012), "Capital Flows, Push versus Pull Factors and the Global Financial Crisis," Journal of International Economics, Vol. 88(2), pp. 341-356.

Frazzini, A., and O. A. Lamont (2008), "Dumb Money: Mutual Fund Flows and the Cross-Section of Stock Returns," Journal of Financial Economics, Vol. 88(2), pp. 299-322.

Goetzmann, W. N., and M. Massa (2003), "Index Funds and Stock Market Growth," The Journal of Business, Vol. 76(1), pp. 1-28.

Granger, C. W. (1969), "Investigating Causal Relations by Econometric Models and Cross-Spectral Methods," Econometrica, Vol. 37, pp. 424-438.

Granger, C. W. (1987), "Developments in the Study of Cointegrated Economic Variables," Oxford Bulletin of Economics and Statistics, Vol. 48, pp. 213-228.

Grinblatt, M., S. Titman, and R. Wermers (1995), "Momentum Investment Strategies, Portfolio Performance and Herding: A Study of Mutual Fund Behavior," American Economic Review, Vol. 85, pp. 1088-1105.

Hendricks, D., J. Patel, and R. Zeckhauser (1993), "Hot Hands in Mutual Funds: Short-run Persistence of Relative Performance, 1974-1988," The Journal of Finance, Vol. 48, pp. 93-130.

Hendry, D. (1986), "Econometrics Modelling with Cointegrated Variables: An Overview," Oxford Bulletin of Economics and Statistics, Vol. 48, pp. 51-63.

IMF (2011), "Global Financial Stability Report: Grappling with Crisis Legacies," International Monetary Fund. 
Ippolito, R. A. (1992), "Consumer Reaction to Measures of Poor Quality: Evidence from the Mutual Fund Industry," Journal of Law and Economics, Vol. 35, pp. 45-70.

Jotikasthira, C., C. Lundblad, and T. Ramadorai (2012), "Asset Fire Sales and Purchases and the International Transmission of Funding Shocks," The Journal of Finance, Vol. 67(6), pp. 2015-2050.

KOFIA (2014), “2014 Capital Market in Korea,” Korea Financial Investment Association.

Khorana, A., H. Servaes, and P. Tufano (2005), "Explaining the Size of the Mutual Fund Industry around the World," Journal of Financial Economics, Vol. 78(1), pp. 145-185.

King, R. G., and R. Levine (1993), "Finance and Growth: Schumpeter might be Right," Quarterly Journal of Economics, Vol. 108(3), pp. 717-738.

Kwiatkowski, D., P. C. Phillips, P. Schmidt, and Y. Shin (1992), "Testing the Null Hypothesis of Stationarity Against the Alternative of a Unit Root: How Sure Are We That Economic Time Series Have a Unit Root?," Journal of Econometrics, Vol. 54(1), pp. 159-178.

Levine, R. (1997), "Financial Development and Economic Growth: Views and Agenda," Journal of Economic Literature, Vol. 35(2), pp. 688-726.

Mark, N. C., M. Ogaki, and D. Sul (2005), "Dynamic Seemingly Unrelated Cointegrating Regressions," The Review of Economic Studies, Vol. 72(3), pp. 797-820.

Oh, N. Y., and J. T. Parwada (2007), "Relations between Mutual Fund Flows and Stock Market Returns in Korea," International Financial Markets, Institutions and Money, Vol. 17(2), pp. 140-151.

Potter, M., and T. Schneeweis (1998), "The Relationship between Aggregate Mutual Fund Flows and Security Returns," Working paper.

Remolona, E., P. Kleiman, and D. Gruenstein (1997), "Market Returns and Mutual Fund Flows," FRBNY Economic Policy Review, Vol.3(2), pp. 33-52. 
Russell, R. (2007), “An Introduction to Mutual Funds Worldwide," John Wiley \& Sons.

Saikkonen, P. (1991), "Asymptotically Efficient Estimation of Cointegration Regressions," Econometric Theory, Vol. 7(1), pp. 1-21.

Sims, C. A. (1972), "Money, Income, and Causality," American Economic Review, Vol. 62, pp. 540-552.

Sirri, E. R., and P. Tufano (1998), "Costly Search and Mutual Fund Flows," The Journal of Finance, Vol. 53(5), pp. 1589-1622.

Stock, J., and M. Watson (1993), "A Simple Estimator of Cointegrating Vectors in Higher Order Integrated Systems," Econometrica, Vol. 61(4), pp. 783-820.

Warther, V. A. (1995), "Aggregate Mutual Fund Flows and Security Returns," Journal of Financial Economics, Vol. 39(2), pp. 209-235. 


\section{$<$ Abstract in Korean>}

\section{한국 자본시장에서 주가변동과 뮤추얼펀드 자금흐름 간의 동태적 관계 분석}

김재범*, 김정민**

본 연구는 해외 뮤추얼펀드의 국내 주식과 채권에 대한 투자자금흐름과 증권가격의 변동 사이의 동태적 관계를 시스템방법을 이용하여 분석하였 다. 2004년 1월부터 2015년 8월까지 분석기간 동안 주식, 채권, 단기자금 시장에서의 가격 및 자금흐름에 관한 월별 자료를 바탕으로 DSUR(Dynamic Seemingly Unrelated Regression), SURECM(Seemingly Unrelated Regression Error Correction Model) 모형을 추정하였는데, 잔차항의 공분 산 행렬 정보를 활용하여 추정치의 효율성을 높였다. 또한, 분석의 강건성 을 위해 뮤추얼펀드의 주식과 채권에 대한 투자자금흐름을 보여주는 이머징 포트폴리오펀드리서치(EPFR) 자료와 함께, 국제수지의 금융계정에 나타 나는 국내주식, 장-단기채권 자금유출입 자료를 이용한 분석도 보고하였다.

분석 결과, 주가변동과 자금흐름 사이에 양 $(+)$ 의 공적분 관계가 있어 장기 적으로는 같은 방향으로 움직임을 확인했고, 이러한 양자간 장기균형에서 벗어나는 충격에 대해 단기적으로는 주식가격은 민감하게 반응하는 반면 자금흐름은 유의하게 반응하지 않는 것으로 나타났으며, 월별자료에 따르 면 외국인 투자자금흐름이 국내 주식시장 움직임에 반응하는 것으로 나타 났다. 이러한 결과는 단기적인 외부충격에 대해 자금흐름보다는 주가의 변 동성이 빠르게 높아질 수 있음을 의미하고, 또한 주가지수의 과도한 변동 성은 외국인 투자자금에 부정적 영향을 줄 수 있음을 시사한다.

핵심주제어: 주가변동, 펀드자금흐름, 공적분, DSUR, SURECM

JEL Classification: G11, C32

* 미국 오클라호마 주립대학교 경제학과 교수

** 서울시립대학교 경영학부 조교수

본 논문은 김정민 교수가 한국은행 경제연구원에 재직 시 작성되었고, 이 연구내용은 집필자의 개인의 견이며 한국은행의 공식견해와는 무관합니다. 따라서 본 논문의 내용을 보도하거나 인용할 경우에는 집필자명을 반드시 명시하여 주시기 바랍니다. 